\title{
Determination of serum cholesterol concentration in the presence of ascorbate
}

\author{
P J Lumb, B M Slavin
}

Department of Endocrinology \& Chemical Pathology St Thomas's Hospital Lambeth Palace Road London SE1 7EM

P J Lumb

B M Slavin

Correspondence to:

Dr P J Lumb 29 September 1992
Accepted for publication

\begin{abstract}
Pretreatment of a serum or plasma sample with ascorbate oxidase removed interfering ascorbate and allowed the determination of cholesterol to be carried out by a current enzymatic cholesterol method available in kit form. The Cobas-Fara was programmed to carry out pretreatment of the sample with ascorbate oxidase before addition of the cholesterol colour reagent.
\end{abstract}

$(\mathcal{F}$ Clin Pathol 1993;46:283-284)

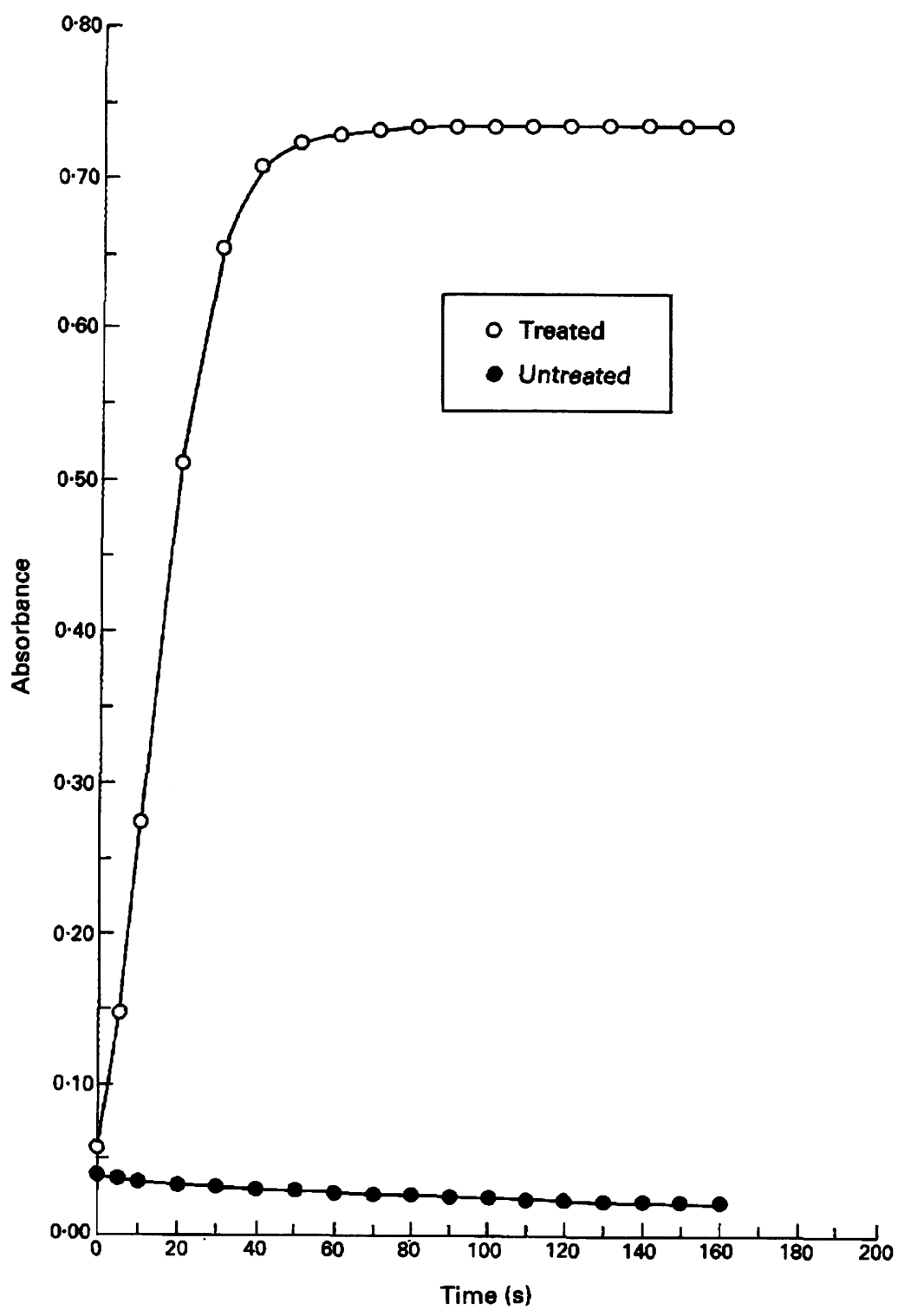

Reaction profile of treated and untreated samples containing ascorbate.
The addition of ascorbate to serum or plasma as an antioxidant may present a problem in subsequent analysis. This is particularly true when the analytical procedure involves enzymatic oxidation generating hydrogen peroxide, which is then used to oxidise a colourless compound in its reduced form to a coloured oxidised derivative.

When the department was asked to determine cholesterol on serum samples to which it was alleged $5 \mathrm{mg} / \mathrm{ml}$ ascorbate had been previously added as an antioxidant, there was little enthusiasm to resurrect the LiebermannBurchard method. It was decided to investigate the possibility of adapting a currently available enzymatic cholesterol method using cholesterol oxidase/peroxidase aminophenazone (CHOD-PAP reagent).

Ascorbic oxidase is an atypical oxidase in that it produces water rather than hydrogen peroxide when catalysing the oxidation of ascorbate to dehydroascorbate. It should therefore be possible to pretreat serum or plasma containing ascorbate with ascorbate oxidase before carrying out an enzymatic cholesterol method.

\section{Method \\ REAGENTS}

Ascorbate oxidase 1000 units (Sigma). This was dissolved in $1 \mathrm{ml}$ acetate buffer, $\mathrm{pH} 5 \cdot 6$, and further diluted 1 in 20 with buffer for use; CHOD-PAP cholesterol reagent for the Kinetic Colorimetric Test ${ }^{1-4}$ (BoehringerMannheim); Precinorm U (PN) Quality Control Serum (Boeringher-Mannheim); Precilip EL. (PEL) Quality Control Serum (Boeringher-Mannheim).

A range of serum ascorbate concentrations from $0-6 \mathrm{mg} / \mathrm{ml}$ were prepared as follows.

One bottle of Precinorm U was reconstituted with a freshly prepared aqueous solution of sodium ascorbate containing $6 \mathrm{mg} / \mathrm{ml}$ (PN + A6). A second bottle of Precinorm U from the same batch was reconstituted with distilled water (PN) and used to prepare a series of dilutions of $\mathrm{PN}+\mathrm{A} 6$ to give a range of ascorbate concentrations as follows: 1 $\mathrm{mg} / \mathrm{ml}(\mathrm{PN}+\mathrm{A} 1) ; 2 \mathrm{mg} / \mathrm{ml}(\mathrm{PN}+\mathrm{A} 2) ; 3$ $\mathrm{mg} / \mathrm{ml}(\mathrm{PN}+\mathrm{A} 3)$; and $4 \mathrm{mg} / \mathrm{ml}(\mathrm{PN}+\mathrm{A} 4)$.

Samples were analysed on the Cobas-Fara programmed to determine cholesterol according to the protocol supplied with the CHODPAP Kinetic Colorimetric Reagent Kit. The protocol was slightly modified to permit pretreatment of samples with ascorbic oxidase prior to the addition of cholesterol reagent. 
Cholesterol determination in the presence of ascorbate

\begin{tabular}{|c|c|c|c|c|c|c|c|c|}
\hline & $\begin{array}{l}\text { Ascorbate } \\
(\mathrm{mg} / \mathrm{ml})\end{array}$ & & Mean & $(S D)$ & (SEM) & Min- & Max- & $\mathrm{CV}^{\circ} \%$ \\
\hline PN & 0 & 12 & $2 \cdot 9$ & & & & & \\
\hline $\mathrm{PN}+1$ & 1 & 3 & $3 \cdot 0$ & & & & & \\
\hline $\mathrm{PN}+2$ & 2 & 3 & 3.0 & & & & & \\
\hline $\mathrm{PN}+3$ & 3 & 3 & $2 \cdot 9$ & & & & & \\
\hline $\mathrm{PN}+4$ & 4 & 12 & $3 \cdot 0$ & & & & & \\
\hline $\mathrm{PN}+6$ & 6 & 12 & $2 \cdot 9$ & & & & & \\
\hline Total & $0-6$ & 45 & $3 \cdot 0$ & $(0.09)$ & $(0 \cdot 01)$ & $2 \cdot 8$ & $3 \cdot 1$ & $3 \cdot 0$ \\
\hline
\end{tabular}

PN: Precinorm U Quality Control Serum

This modification allowed for the addition of $20 \mu \mathrm{l}$ ascorbic oxidase reagent plus $10 \mu \mathrm{l}$ water diluent to $3 \mu \mathrm{l}$ of sample (instead of 30 $\mu \mathrm{l}$ of water diluent used normally), followed by a preincubation at $37^{\circ} \mathrm{C}$ for 10 minutes before the addition of cholesterol reagent and subsequent colour development.

Precinorm U and Precilip EL are used as a quality control serum and calibrant, respectively, in the routine determination of cholesterol and were used similarly in this modified method. PN + A4 was also used as an additional quality control serum when analysing samples by this method.

\section{Results}

The table shows the results obtained, and the graph compares changing absorbance with time as the reaction proceeds (reaction profile). The graph clearly shows the inhibitory effect of ascorbate on the colour reaction, which is readily overcome after treatment with ascorbic oxidase.

The same batch of Precinorm U, when used as a quality control for the routine determination of cholesterol, gave an average value of $2.92 \mathrm{mmol} / \mathrm{l}$. The quoted range of this batch of quality control serum was given as $2 \cdot 43-3.2 \mathrm{mmol} / \mathrm{l}$, with a mean of $2 \cdot 82$ $\mathrm{mmol} / \mathrm{l}$.

\section{Conclusion}

When ascorbate has been added to serum or plasma samples as an antioxidant, current analytical methods which rely on oxidation to produce a coloured compound, can be used, providing the sample is pretreated with ascorbic oxidase. This enzyme pretreatment can be incorporated into an automated analytical procedure with minimal change in the method protocol.

We thank Professor Donald Moss, Chemical Pathology Department, Royal Post Graduate Medical School, London, for his helpful advice and comments.

1 Deeg R, Ziegenhorn J. Kinetic enzymatic method for automated determination of serum total cholesterol. Clin Chem 1982;28:1574.

2 Katterman R, Jaworek D, Moller G, et al. Multicentre study of a new enzymatic method of cholesterol determination. $f$ Clin Chem Clin Biochem 1984;22:245-51.

3 Siedel J, Hagele EO, Ziegenhorn J, Wahlefeldt AW. Reagent for the enzymatic determination of serum total cholesterol with improved lipolytic efficiency. Clin Chem 1983;29:1075-80.

4 Trinder P. Determination of glucose in blood using glucose oxidase with an alternative oxygen acceptor. Ann Clin Biochem 1969;6:24-7. 